Andrews University

Digital Commons @ Andrews University

\title{
Psychological Types and Temperaments: A Correlational Study Using the Myers-Briggs Type Indicator and the Temperament Inventory
}

Ronda F. Daugherty

Andrews University

Follow this and additional works at: https://digitalcommons.andrews.edu/theses

Part of the Psychological Phenomena and Processes Commons

\section{Recommended Citation}

Daugherty, Ronda F., "Psychological Types and Temperaments: A Correlational Study Using the MyersBriggs Type Indicator and the Temperament Inventory" (1995). Master's Theses. 178.

https://dx.doi.org/10.32597/theses/178

https://digitalcommons.andrews.edu/theses/178

This Thesis is brought to you for free and open access by the Graduate Research at Digital Commons @ Andrews University. It has been accepted for inclusion in Master's Theses by an authorized administrator of Digital Commons@ Andrews University. For more information, please contact repository@andrews.edu. 


\section{PSYCHOLOGICAL TYPES AND TEMPERAMENTS: A CORRELATIONAL STUDY USING THE MYERS- BRIGGS TYPE INDICATOR AND THE TEMPERAMENT INVENTORY}

by

Ronda F. Daugherty

Chair: Wilfred G. A. Futcher 


\title{
ABSTRACT OF GRADUATE STUDENT RESEARCH \\ Thesis
}

\author{
Andrews University \\ School of Education
}

Title: PSYCHOLOGICAL TYPES AND TEMPERAMENTS: A CORRELATIONAL STUDY USING THE MYERS-BRIGGS TYPE INDICATOR AND THE TEMPERAMENT INVENTORY

Name of researcher: Ronda F. Daugherty

Name of degree of faculty chair: Wilfred G. A. Futcher, Ph.D. Date completed: July, 1995

Problem

The purpose of this study was to determine whether there is a significant relationship between the construct of psychological types, as measured by the Myers-Briggs Type Indicator (MBTI), and temperaments, as measured by the Temperament Inventory (TI).

\section{Method}

A non-random sample of 113 individuals completed a demographic questionnaire, the MBTI, and the TI. The results of each preference score of the MBTI and the scores on each of the four temperaments from the TI were compared using a 
canonical correlation analysis.

\section{Results}

There is a significant relationship between the MBTI's psychological types and the TI's temperaments. A preference for extroversion on the MBTI was correlated with a sanguine temperament, while preferences for thinking and judging on the MBTI were correlated with a choleric temperament.

Conclusions

The constructs of psychological types and temperaments should not be considered to be completely independent. 


\title{
Andrews University \\ School of Education
}

PSYCHOLOGICAL TYPES AND TEMPERAMENTS: A CORRELATIONAL STUDY USING THE MYERS-

BRIGGS TYPE INDICATOR AND THE

TEMPERAMENT INVENTORY

\author{
A Thesis \\ Presented in Partial Fulfillment \\ of the Requirements for the Degree \\ Master of Arts
}

by

Ronda E. Daugherty

July 1995 

PSYCHOLOGICAL TYPES AND TEMPERAMENTS: A CORRELATIONAL STUDY USING THE MYERS-BRIGGS TYPE INDICATOR AND THE TEMPERAMENT INVENTORY

A thesis

presented in partial fulfillment of the requirements for the degree

Master of Arts

by

Ronda F. Daugherty

APPROVED BY THE COMMITTEE:

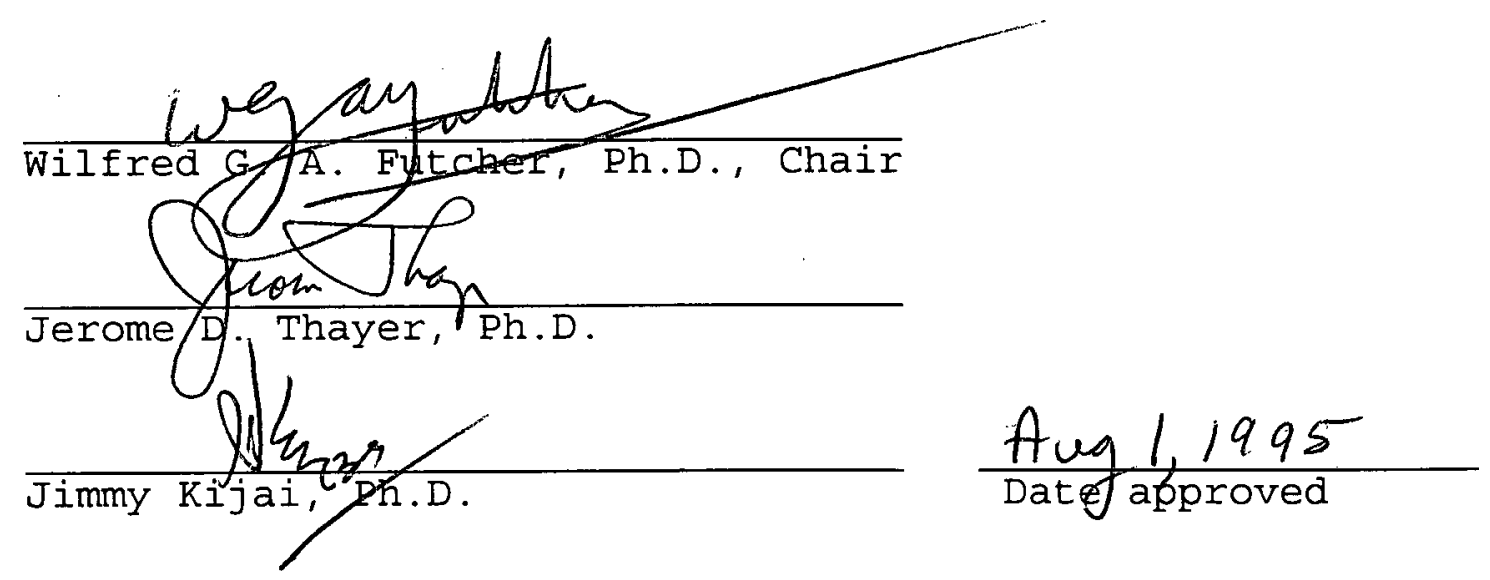


DEDICATION

To the memory of my loving brother, Ronald R. Funderburk II 
TABLE OF CONTENTS

LIST OF TABLES

vi

ACKNOWLEDGMENTS

vii

Chapter

I. INTRODUCTION . . . . . . . . . . . . . . . . 1

Statement of the Problem . . . . . . . . . 1

Purpose of Study . . . . . . . . . . . . . 2

Definition of Terms . . . . . . . . . . . 3

Research Hypothesis . . . . . . . . . 5

II. REVIEW OF RELATED LITERATURE . . . . . . . . 6

Overview . . . . . . . . . . . . . . . 6

The MBTI . . . . . . . . . . . . . . . 6

Development of the MBTI . . . . . . . 6

Defining the Four MBTI Functions . . . 9

Output of the MBTI . . . . . . . . . . 10

The MBTI and Temperament . . . . . . . 11

The TI . . . . . . . . . . . . . . . 12

Development of the TI . . . . . . . . 12

Defining the Four Temperaments . . . . 13

Output of the TI . . . . . . . . . . 14

Synopsis of Literature . . . . . . . . . 15

III. METHODOLOGY • . . . . . . . . . . . . . . . 16

Subjects . . . . . . . . . . . . . . . . 16

Instrumentation . . . . . . . . . . . . . 17

The MBTI . . . . . . . . . . . . . 17

Reliability and validity . . . . . 18

The TI . . . . . . . . . . . . . . 21

Reliability and validity . . . . . . 21

The Demographic Questionnaire . . . . . 23

Data Collection . . . . . . . . . . . 23

The MBTI . . . . . . . . . . . . . . . 23

The TI . . . . . . . . . . . . . . 24

Null Hypothesis . . . . . . . . . . . 25 
IV. DATA ANALYSIS . . . . . . . . . . . . . . . . 26

Methods . . . . . . . . . . . . . . . . 26

Results . . . . . . . . . . . . . . . 26

Interpretation . . . . . . . . . . . . 30

V. SUMMARY, CONCLUSIONS, AND RECOMMENDATIONS . . 32

Summary . . . . . . . . . . . . . . . . . 32

Problem and Purpose . . . . . . . . . 32

Literature Review . . . . . . . . . . . 32

Methodology . . . . . . . . . . . . . 33

Findings . . . . . . . . . . . . . . 33

Conclusions . . . . . . . . . . . . . . . 34

Recommendations : . . . . . . . . . . . 34

APPENDIX . . . . . . . . . . . . . . . . 36

BIBLIOGRAPHY . . . . . . . . . . . . . . . . . . . . 49

VITA . . . . . . . . . . . . . . . . 51 


\section{LIST OF TABLES}

1. 4 x 4-Type Table . . . . . . . . . . . . . . 11

2. Demographic Make-up of Survey Respondents . . . 17

3. Test-retest Agreement of Type Categories . . . . 20

4. Descriptive Statistics . . . . . . . . . . . 27

5. Correlation Matrix . . . . . . . . . . . . 27

6. Bartlett's Test for Remaining Eigenvalues . . . 29

7. Canonical Variable Loadings . . . . . . . . . . 30 


\section{ACKNOWLEDGMENTS}

I would like to thank Dr. Futcher for his encouragement and leadership in completing this long-distance project. And thank you to my wonderful husband Patrick, who encouraged me not to give up. . 
CHAPTER 1

INTRODUCTION

\section{Statement of the Problem}

An individual's personality defines the person, and makes him or her different from everyone else. At the same time, everyone seems to share a finite number of personality characteristics. If we can understand another person's personality, we better understand how to relate to that person, how to interact with him or her, and the type of behavior to expect from him or her in certain situations.

Throughout history, scientists and philosophers have proposed a variety of theories to determine how people's personalities differ. These theories are the ideas about how and why people feel, think, and act the way they do. Most theories incorporate the traditional assumption of personality theory that an individual's characteristics are relatively enduring and that they do not change in meaningful ways from one situation to another (White \& Speisman, 1982). The interest of researchers is increasing. Plomin and Dunn (1986) noted that the amount of personality research increased every year from 1970 - 
1983. Among the many theories of personality that have developed are those of (1) psychological types and (2) temperaments.

The mostly commonly used method of studying personality is the use of a "personality test." Many psychological tests, or instruments, have been developed to examine different aspects or theories of personality, including the theories of psychological types and temperaments. For the purposes of most research, the theories of psychological types and temperaments have been viewed as separate and unrelated, even though in many areas the theories are similar. However, little research has been done to show an empirical relationship between the two constructs. Windle (1989) states, "Exploring inter-inventory relations facilitates the comparison of constructs which may be labeled similarly (or differently) in various instruments and yet may manifest intercorrelations ranging anywhere from negative one to positive one" (p. 487).

\section{Purpose of Study}

The purpose of this study was to determine whether there is a relationship between psychological types, as measured by the Myers-Briggs Type Indicator (MBTI), and temperaments, as measured by the Temperament Inventory (TI). This analysis used quantitative measures to empirically determine the amount of overlap and/or 
independence of the constructs measured by these two instruments.

In general, the theory of personality types tries to explain how an individual perceives and thinks about the world around them. The MBTI was "designed explicitly to make it possible to test $C$. J. Jung's theory of psychological types and to put it to practical use" (Myers \& McCaulley, 1985, p. 11). The theory of temperaments tries to explain how a person will respond to their perceptions. The TI expands on Eysenck's four-temperament theory with the ability to score an individual on each of the four temperament scales separately (Cruise, Blitchington, \& Futcher, 1980).

If a significant relationship exists between the four factors of temperament theory and each of the four factors in Jung's personality type theory we would be able to explain how an individual perceives their environment by their actions, or how someone will react to their environment based on their perceptions and judgments. If there is no relationship between the two constructs we should continue to view them as separate.

\section{Definition of Terms}

The theory of psychological types refers to an individual's preferences in using perception and judgment. Perception is defined as becoming aware of things, and judgment is defined as the way an individual makes 
conclusions about what has been perceived (Myers \& McCaulley, 1985). The theory of temperament provides a potential framework for explaining and predicting how the unique characteristics of individuals influence their responses to the world around them (McClowry, 1992). Giovannoni, Berens, and Cooper (1988) feel that there are basic differences in the theoretical perspectives of psychological types and temperaments. They state that while psychological types are constructs of mental processes, temperaments are constructs of activity patterns.

Hippocrates first suggested a four-factor theory of temperament (sanguine, melancholic, choleric, and phlegmatic) in 400 B.C. The four Spirit Keepers of the American Indian Medicine wheel are also suggestive of four temperament patterns, as are the four desires comprising Hindu wisdom (Plomin \& Dunn, 1986). Galen of Pergamum (A.D. 130-200) proposed the theory that four humours (fire, earth, air, and water) were the elements of all things, and that a person's physical constitution and psychological characteristics were determined by balancing, or blending the four humours. Galen's theory is the descriptive typology of character, which emerged in the 18th and 19th centuries, and which resembles the extroversion and neuroticism dimensions proposed by Eysenck's theory of temperament today (Stelmack \& Stalikas, 1991). Plomin and Dunn (1986) attribute the 
beginning of the modern history of temperament research to Thomas and Chess and their New York Longitudinal Study.

In 1920, C. G. Jung contended that people are different in fundamental ways even though they all have the same instincts to drive them. Our preference for a given "function" is characteristic, and so we may be "typed" by this preference. Thus, Jung invented the "function types" or "psychological types" (Keirsey \& Bates, 1984) .

\section{Research Hypothesis}

By looking at the two constructs of psychological types and temperaments, the hypothesis that there is a statistically significant relationship between psychological types and temperaments as measured by the MBTI and the TI was proposed. This enables us to infer relationships between the four temperaments of the TI and the 16 psychological types of the MBTI. 
CHÁPTER 2

REVIEW OF RELATED LITERATURE

\section{Overview}

In completing the research for this analysis, a large number of four factor-theories of personality was encountered. Jung, Myers, Buss, Plomin, Eysenck, and Keirsey are just a few of the theorists with variations on a four-factor theory. Other theories, such as Cloninger's three-factor model and Digman's five-factor model, were also reviewed. In addition, a significant amount of research into the temperament of children was found.

However, the research for this paper focused on the theories behind the development of the MBTI and the TI-those of Jung, Myers, and Eysenck.

\section{The MBTI}

Development of the MBTI

The MBTI was developed specifically to test Jung's theory of psychological types and is one of the few instruments that attempts to measure Jungian constructs. Jung distinguished four basic kinds of mental activity: thinking, feeling, sensing, and intuition, with four 
corresponding kinds of introversion and extroversion (Diamond, 1957). He later classified these constructs into his four function types. The MBTI alleges to measure types rather than traits and is often used to explain an individual's personality characteristics to professionals and individuals.

Myers and McCaulley (1985) note that Jung described the functions of extroversion-introversion (EI), sensingintuition (SN), and thinking-feeling ( $\mathrm{TF}$ ) explicitly in his work, while the importance of judgment and perception (JP) was implicit. Jung theorized that individuals related to the world through two sets of opposing functions: the judging functions of thinking and feeling and the perceiving functions of sensing and intuition. It was his view that one of these functions is seen as the dominant, and the second as the auxiliary function (McCrae \& Costa, 1989). In the development of the MBTI, Isabel Myers and Katherine Briggs assigned two uses to the JP function. "The recognition and development of facts about the JP function are a major contribution of Briggs and Myers to the theory of psychological types" (Myers \& McCaulley, 1985, p. 13). The JP function describes identifiable attitudes and behaviors to the outside world and is used, in conjunction with the EI function, to identify which of the two preferred functions is the leading or dominant function and which is the auxiliary (Myers \& McCaulley, 1985). 
In addition to eight preference types described by Jung, Myers and Briggs used the following assumptions in developing the MBTI:

1. For each type, one function will be dominant. This is the first function.

2. Members of each type will use mainly their first function in the favorite attitude. That is, extroverts use the dominant function mainly in the outer world of extroversion; introverts use the dominant function mainly in the introverted world of concepts and ideas.

3. In addition to the first or dominant function, a second or auxiliary function will develop.

4. The second function provides balance between introversion and extroversion.

5. The second function also provides a balance between perception and judgment.

6. For both extroverts and introverts, the JP preference points to the function used in the extroverted attitude.

7. If the dominant function is typically introverted, the other three functions are typically extroverted. If the dominant function is typically extroverted, the other three are typically introverted (Myers \& McCaulley, 1985).

The construction of the MBTI was also based on the assumptions that (1) true preferences for one pole of a function actually existed, (2) that a person could give an 
indication of the preferences that combine to form type, directly or indirectly on a self-report inventory, that preferences are dichotomized, and (4) that the two poles of a preference are equally valuable (Myers \& McCaulley, 1985). McCrae and Costa (1989) point out that Myers and Briggs also relied heavily on their own observations of individuals they considered as examples of different types and on traditional psychometric procedures, such as item-scale correlations.

\section{Defining the Four MBTI Functions}

Extroversion and Introversion: The attitudes of extroversion and introversion are seen as complementary attitudes towards life. Individuals with an extroverted attitude have an awareness and reliance on their environment for stimulation and guidance. They are sociable and enjoy people. Individuals with an introverted attitude rely on themselves and are more interested in concepts and ideas.

Sensing and Intuition: The functions of sensing and intuition deal with how an individual perceives the flow of events in life. An individual oriented toward sensing tends to focus on what is happening at the present moment, while an individual who relies on intuition sees possibilities beyond what is visible to the senses.

Thinking and Feeling: Thinking and feeling are functions that focus on harmonizing life events with the 
laws of reason. Thinking individuals are often objective and critical; they rely on the principles of cause and effect. People with an orientation toward feeling base their decisions on subjective values; they have a good understanding of people.

Judging and Perceiving: In addition to describing attitudes and behaviors, the judging and perceiving function is used with the extroversion and introversion functions in determining dominant and auxiliary functions. Judging types are concerned with decision making and logical analysis. They often appear organized and decisive. Individuals with a perceptive attitude are aware of what is going on around them and are often spontaneous and adaptable (Myers \& McCaulley, 1985).

\section{Output of the MBTI}

The MBTI dichotomizes each of the four scales at a theoretically fixed zero point to show a preference for one end of each scale: EI, SN, TF, and JP. It also provides a four-letter classification code for an individual's type preference. The first letter is an individual's preference of extroversion (E) or introversion (I); the second his or her preference for sensing (S) or intuition (N); the third his or her preference for thinking ( $T$ ) or feeling ( $F)$; and the fourth letter his or her preference for judging (J) or perceiving (P). Table 1 is a 4 x 4-type table developed to highlight 
the similarities and differences of types by their placement.

Table 1

4 X 4-Type Table

\begin{tabular}{|c|c|c|c|}
\hline ISTJ & ISFJ & INFJ & INTJ \\
\hline ISTP & ISFP & INFP & INTP \\
\hline ESTP & ESFP & ENFP & ENTP \\
\hline ESTJ & ESFJ & ENFJ & ENTJ \\
\hline
\end{tabular}

Each type has three letters in common with any adjacent type. Introverted types appear in the first and second rows, extroverted types in rows 3 and 4 . The mnemonic aid for EI placement is that introverts are more likely to have their heads "up" in the clouds; extroverts are more likely to have their feet "down" on the ground. sensing types and intuitive types are positioned as they are named on the SN index, with sensing on the left and intuition on the right. Feeling types, with their higher need for affiliation, are the two inner columns surrounded by other types. The more objective thinking types are in the outer columns. The decisive judging types are on the top and bottom rows, and the more adaptable perceptive types are in the middle rows (Myers \& McCaulley, 1985).

The MBTI and Temperament

Giovannoni et al. (1988) used the MBTI to study the 
construct of temperament as well as psychological types. "Although designed for use with a different theoretical framework, the MBTI seems to work with reasonable accuracy for identifying temperament as well" (p. 1). Keirsey and Bates (1984) discuss a similar form of temperament with the MBTI as a basis. These temperament theories focus on the combinations of the SN, TF, and JP indices of the MBTI .

\section{The TI}

Development of the TI

The TI is one of the few scientifically researched instruments based on the four-temperament theory (Blitchington \& Cruise, 1979). It was developed as an extension of Eysenck's four-temperament theory. His instrument, the Eysenck Personality Inventory (EPI), measures two dimensions of personality: introversion/extroversion and high/low neuroticism. Combined, these yield four temperaments: neurotic introvert, neurotic extrovert, stable introvert, and stable extrovert (Cruise et al., 1980). Eysenck's four temperaments correspond to the four temperaments suggested by Hippocrates: melancholic, choleric, phlegmatic, and sanguine.

Buss and Plomin (1975) have also done considerable research on a four-temperament theory. They developed the EASI Temperament Survey (EASI) to measure the temperaments 
of emotionality, activity, sociability, and impulsivity. Unlike the EPI, the EASI provides a score on each of the four temperaments. However, it does not retain Eysenck's original temperament scheme.

In developing the TI, Cruise et al. (1980) retained Eysenck's original four-temperament scheme with the added capacity to score separately an individual on each of the four temperament scales. This allows an individual to look at the combination of temperaments when explaining personality. Blitchington and Cruise (1979) felt that this was an important addition to Eysenck's theory "because the traits and behaviors usually associated with on the temperament can be modified or changed around depending on the secondary temperament $(s) "(p .15)$.

\section{Defining the Four Temperaments}

Choleric: Cholerics are generally bold and aggressive in social situations. They tend to be argumentative and insensitive to the needs and feelings of others. Cholerics are often full of energy and can be very efficient and productive if the energy is channeled into a specific task.

Sanguine: Sanguines are friendly, talkative, and outgoing. When sanguines are with other people they are usually cheerful and expressive. However, they are also easily distracted by new objects or events. Often, a sanguine's distractible nature makes them appear 
unorganized.

Melancholy: Melancholics have a lot of emotional energy and anxiety, which may cause them to perform poorly under pressure. They are often seen as moody and sensitive to criticism. Melancholics are very creative and have good problem-solving skills. They have high standards for themselves and others, sometimes unobtainably high, which can cause melancholics to punish themselves for falling below their own standards.

Phlegmatic: Phlegmatics are calm and easygoing. They are good peacemakers and do not like conflict. Phlegmatics adapt easily to new environments, people, and procedures. Their actions are unhurried and deliberate and are sometimes seen by others as bland.

\section{Output of the TI}

The TI provides a raw score and a percentile rank for that score on each of the four temperaments. The higher the percentile rank, the more personality characteristics of that temperament are seen in the individual. In contradiction to some theorists, the TI does not subscribe to the idea of mutual exclusion among the four temperaments. The combination of percentile ranks across temperaments is to be used by individuals to describe themselves across multiple temperaments. This is the key to the interpretation of the $\mathrm{TI}$, since

a person who scores at the 85 th percentile on the sanguine scale and the 50th percentile on the 
melancholic scale (a sanguine-melancholy) will be somewhat different from a person who scores at the 85 th percentile on the sanguine scale and at the 60 th percentile on the phlegmatic scale (a sanguinephlegmatic). (Blitchington \& Cruise, 1979, p. 15)

\section{Synopsis of Literature}

The MBTI is the predominant instrument used to measure the Jungian constructs of psychological types. The four functions, or types, purportedly measured by the MBTI are EI, SN, TF, and JP. An individual's type is measured by a four-letter classification representing his or her preference on each of the four functions, such as ESFP.

A four-factor theory of temperament is measured by only a few instruments, one of which is the TI. The TI is based on Eysenck's theory of temperament. It differs from the Eysenck Personality Inventory by allowing an individual to receive a temperament score on each of the four temperament scales, Choleric, Sanguine, Melancholic, and Phlegmatic. An individual is assigned a raw score and a percentile rank on each scale. 
CHAPTER 3

METHODOLOGY

\section{Subjects}

A non-random sample of 113 individuals volunteered to complete a demographic questionnaire, Form $G$ of the MBTI, and the TI. A copy of each of these instruments is provided in the Appendix. The individuals were provided with the results of the MBTI and the TI if they so requested.

The sample consisted largely of graduate students from Andrews University and research and marketing professionals from Chicago. The sample was comprised of 47 males ( $42 \%$ ) and 66 females (58\%). The average respondent was White, and in his or her early 30s, and lived in the Midwest. The average age of respondents was 32, with a median age of 29 and a range from 14 to 60 . The sample was heavily weighted toward Whites between the ages of 18 and 44 . Table 2 provides a breakdown of the race, gender, and ages of the respondents. Two respondents did not provide this demographic information and are excluded from Table 2 .

Myers and McCaulley (1985) indicate that the MBTI is 
Table 2

Demographic Make-up of Survey Respondents

\begin{tabular}{|c|c|c|c|c|c|c|c|}
\hline $\begin{array}{c}\text { Age } \\
\text { Group }\end{array}$ & $\begin{array}{l}\text { White } \\
\text { Males }\end{array}$ & $\begin{array}{l}\text { White } \\
\text { Females }\end{array}$ & $\begin{array}{l}\text { Black } \\
\text { Males }\end{array}$ & $\begin{array}{c}\text { Black } \\
\text { Females }\end{array}$ & $\begin{array}{l}\text { Other } \\
\text { Males }\end{array}$ & $\begin{array}{c}\text { Other } \\
\text { Females }\end{array}$ & Totals \\
\hline$<18$ & & 7 & & & 1 & & 8 \\
\hline $18-24$ & 15 & 12 & & & & & 27 \\
\hline $25-34$ & 9 & 10 & & 2 & 1 & 2 & 24 \\
\hline $35-44$ & 9 & 20 & & 2 & & & 31 \\
\hline $45-54$ & 7 & 5 & 1 & 1 & & & 14 \\
\hline$>54$ & 3 & 3 & & & 1 & & 7 \\
\hline Totals & 43 & 57 & 1 & 5 & 3 & 2 & 111 \\
\hline
\end{tabular}

appropriate for use with adults and high-school students with a seventh- to eighth-grade reading level (p. 6) . Since there are no corresponding published guidelines for use of the TI, the same guidelines were used. The respondents in the sample used here fit this general profile.

\section{Instrumentation}

The MBTI

The MBTI was developed by Isabel Myers and Katharine Briggs in the early 1960s. It was chosen as the instrument to measure psychological types based on its popularity and the large amount of research that has been done to support its use. The form chosen for administering the MBTI, Form G, is self-scorable and 
virtually self-administering. It consists of 126 questions. Most items have a forced choice between two responses (because of the dichotomies postulated by the type theory), although some have more response options, and respondents are sometimes allowed to endorse more than one response. The preference score for each function consists of a letter showing the direction of the preference and a number showing the strength of the preference. Preference is determined by the greater of the two preference scores, with provisions for breaking ties, and a four-letter code summarizes all four sets of preferences and specifies the type into which the individual is classified (Myers \& McCaulley, 1985). This form made administering the MBTI to the sample of individuals relatively easy and allowed study participants immediate feedback of their psychological types as measured by the MBTI.

The reliability and statistical validity of the MBTI have been proven and tested in the development of each form. In addition, many validation studies have verified the four psychological types and the use of the MBTI.

Reliability and validity

In developing the MBTI, two forms of reliability were measured: internal consistency reliability and test-retest reliability. It was verified that the estimates of internal consistency reliabilities, as 
estimated by coefficient alpha, for the continuous scores of the MBTI scales were acceptable for most adult samples. A sample of 9,216 individual results from the MBTI data bank had the following results for coefficient alpha (decimals have been omitted): $\mathrm{EI}, 83$; SN, 83; TF, 76; JP, 80. Note that the TF function was found to have the lowest reliability (Myers \& McCaulley, 1985).

All measures of test-retest reliabilities of the MBTI showed consistency over time. The reliability methods used included the correlations of continuous scores, the proportion of cases assigned the same direction of preference on retest, and the percentage of cases reporting the same four preferences on retest. A trend was found that showed most changes in preference occurring in cases where the original preference score was low. Table 3 shows a summary of test-retest agreement of type categories for a number of samples. The numbers in the third set of columns of Table 3 reflect the percentage of respondents who had the same preference score on that function at retest. The fourth set of columns indicates the percentage of individuals for which $4,3,2$, or 1 preference scores did not change on retest.

The validity of the MBTI was determined by its ability to classify individuals into each of Jung's psychological types. Content validity of the MBTI, construct validity, and concurrent validity were addressed in the creation of the MBTI. Myers and McCaulley (1985) 
Table 3

Test-retest Agreement of Type Categories

\begin{tabular}{|c|c|c|c|c|c|c|c|c|c|c|}
\hline \multirow[t]{2}{*}{$N$} & \multirow[t]{2}{*}{$\begin{array}{c}\text { Test- } \\
\text { Retest } \\
\text { Interval }\end{array}$} & \multicolumn{4}{|c|}{$\begin{array}{c}\text { \% of Agreement } \\
\text { in each MBTI } \\
\text { Category }\end{array}$} & \multicolumn{5}{|c|}{$\begin{array}{c}\circ \text { of Categories } \\
\text { Unchanged on } \\
\text { Retest }\end{array}$} \\
\hline & & EI & SN & $\mathrm{TF}$ & JP & 4 & 3 & 2 & 1 & 0 \\
\hline 126 & 14-17 mos. & 76 & 87 & 75 & 77 & 37 & 44 & 16 & 4 & 0 \\
\hline 329 & 2 years & 74 & 71 & 73 & 77 & 31 & 39 & 22 & 7 & 0 \\
\hline 177 & 5 weeks & 81 & 89 & 83 & 84 & 48 & 37 & 13 & 0 & 0 \\
\hline 120 & 4.5 years & 72 & 66 & 68 & 66 & 24 & 37 & 29 & 8 & 0 \\
\hline
\end{tabular}

Note. From Manual: A Guide to the Development and Use of the Myers-Briggs Type Indicator (p. 173), by I. B. Myers and M. H. McCaulley, 1985, Palo Alto, CA: Consulting Psychologists Press. Copyright 1985 by Peter B. Myers and Katherine D. Myers.

indicate that item selection was based only on the empirical evidence that the items separated persons with opposing preferences. Items were analyzed on all preferences, and those with high correlations on more than one preference scale were eliminated. The item correlations ranged from 0.92 to 0.22 .

Construct validity of the MBTI was confirmed by noting the consistency of the behavior of the MBTI types with behavior predicted by theory.

The concurrent validity was verified by the fact that the MBTI continuous scores correlated in the expected directions with other instruments that appeared to be testing the same constructs, such as the California Psychological Inventory, the Jungian Type Survey, and the Eysenck Personality Questionnaires. 
Johnson and Saunders (1990) completed a confirmatory factor analysis on the MBTI. Their results validated the four-factor theory as well-defined constructs.

The TI

There are fewer instruments that measure psychological temperaments. One of the most popular measures developed by Keirsey and Bates (1984) was not selected since its development was based on many of the same constructs as the MBTI.

The TI, developed by Cruise et al. in the early 1980s, was chosen to be administered alongside the MBTI. There is only one format of the TI; it can be selfadministered and scored. Immediate feedback was available to study participants about their temperament, as measured by the TI.

The TI consists of 80 statements that require a "Yes" (this is like me) or "No" (this is not like me) response. Five of the items are counted on two factors because they had loadings over 0.30 on each of the two factors and were judged to be valid on both. The scores on each of the four factors are expressed in percentile ranks after summing the number of "like me" responses (or "unlike" responses in the case of a negative item loading on the factor).

Reliability and validity Reliability of each of the four TI factors was 
verified during the development of the instrument by the use of Cronbach's Coefficient Alpha, an estimate of internal consistency. Reliability estimates for the four subscales were: (1) Phlegmatic $=0.88$, (2) Choleric $=$ 0.84 , (3) Sanguine $=0.90$, and (4) Melancholic $=0.88$ (Cruise et al., 1980).

Content validity, construct validity, and concurrent validity were each studied during the development of the TI. Content validity was determined by a panel of judges based on the definitions of temperament suggested in the Iiterature and whether items were clearly worded. A factor analysis was also completed to determine the content validity of each item. Items exhibiting low variance and skewness were eliminated, as were items with factor loadings below 0.30 (Cruise et al., 1980).

Construct validity was verified using a factor analysis yielding four factors hypothesized as the components of temperament. Concurrent validity was tested using the Eysenck Personality Inventory. Using factor scores, there was agreement on two factors in $34 \%$ of cases, agreement on one factor in 61\%, and agreement on zero factors in only 5\% of cases (Cruise et al., 1980).

A factor analysis confirmed the presence of four factors. The distribution of factor scores using the factor score coefficients on all items and the distribution from the four subtests of items (where new factor scores were obtained for each respondent by summing 
the number of responses to the items included in that factor) were compared using the Product Moment Correlation Coefficient. The results from 3,409 respondents:

Phlegmatic, $r=0.86$; (2) Sanguine, $r=0.98$; (3) Choleric, $r=0.95$; (4) Melancholic, $r=0.83$ (Cruise et al., 1980).

\section{The Demographic Questionnaire}

A demographic questionnaire was created in order to tabulate demographic statistics on the make-up of the sample. By having a separate questionnaire, individuals who wished to do so could remain anonymous. The questionnaire asked the individual's gender, age, number of years of schooling completed, state of residence, and race. A copy of the questionnaire can be found in the Appendix .

\section{Data Collection}

The information from the demographic questionnaire and the results of the MBTI and TI were entered into a SPSS/PC+ database for further analysis.

\section{The MBTI}

In order to complete a correlational analysis using the MBTI, the individual raw scores for each of the four preferences were totalled and converted to continuous scores. This allowed treatment of the dichotomous preference scores as continuous scales. Raw scores consist of a letter denoting the pole of the preference on 
each factor. Points for each pole of the preference are compared, the pole with the greater number of points is determined to be the preference score. For example, if an individual scored 18 on the $E$ pole and 7 on the $I$ pole of the EI index, his or her preference score for the EI index would be $\mathrm{E}$ with a numeric preference score of 18 .

For $E, S, T$, or $J$ preference scores, the continuous score is calculated by taking 100 minus the numerical portion of the preference score. For I, N, F, or $\mathrm{P}$ preference scores, the continuous score is 100 plus the numerical portion of the preference score (Myers \& McCaulley, 1985). The continuous scores correspond to the difference between opposing preferences and have a theoretical neutral point of 100 . There were no missing preference scores.

\section{The TI}

The individual raw scores for each of the four factors from the TI were converted to percentile ranks for reporting to respondents. The percentile ranks were converted to standardized $T$ scores for analysis using the following formula: $\quad T=50+10 z . \quad z$ was determined from the percentile rank and a normalized table. The $T$ scores were used in the correlational analysis with the continuous scores from the MBTI. There were no missing percentile ranks. 
Null Hypothesis

The null hypothesis states: There is no significant canonical correlation between a linear combination of the four TI variables and a linear combination of the four MBTI variables. 
CHAPTER 4

DATA ANALYSIS

\section{Methods}

The MBTI continuous scores and the TI standardized scores were analyzed using the canonical correlation analysis method developed by Hotelling with a 0.05 significance level. Tatsuoka (1988) noted that the most common application of canonical analysis was that of seeking relationships between two sets of variables. Canonical analysis helps to answer the question: What combination of MBTI preferences tend to be associated with what combination of TI scores? The results of the canonical correlation were examined to determine whether there was any significant linear relationship between the two sets of variables.

\section{Results}

The first step of analysis was to run descriptive statistics on the data. Table 4 shows the mean, standard deviation, and minimum and maximum values for the standard scores from the MBTI and the TI. The next step was a simple correlation between each of the variables of the 
Table 4

Descriptive statistics

\begin{tabular}{lcccc}
\hline Variable & Mean & $\begin{array}{c}\text { Standard } \\
\text { Deviation }\end{array}$ & $\begin{array}{c}\text { Minimum } \\
\text { Standard } \\
\text { Score }\end{array}$ & $\begin{array}{c}\text { Maximum } \\
\text { Standard } \\
\text { Score }\end{array}$ \\
\hline Phlegmatic & 49.956 & 9.868 & -2.22 & 1.52 \\
Sanguine & 49.938 & 10.031 & -1.89 & 1.60 \\
Choleric & 50.150 & 10.162 & -1.98 & 1.26 \\
Melancholy & 50.097 & 10.073 & -1.70 & 2.08 \\
EI & 100.027 & 27.240 & -1.95 & 2.09 \\
SN & 97.035 & 30.687 & -1.89 & 2.35 \\
TF & 94.540 & 23.420 & -2.54 & 1.90 \\
JP & 96.558 & 29.161 & -1.77 & 2.14 \\
\hline
\end{tabular}

Table 5

Correlation Matrix

\begin{tabular}{|c|c|c|c|c|c|c|c|c|}
\hline & Phleg & Sang & Chol & Melan & EI & SN & $\mathrm{TF}$ & $\mathrm{JP}$ \\
\hline Phleg & 1.000 & & & & & & & \\
\hline Sang & 0.080 & 1.000 & & & & & & \\
\hline Chol & 0.122 & -0.020 & 1.000 & & & & & \\
\hline Melan & -0.613 & -0.304 & -0.331 & 1.000 & & & & \\
\hline $\mathrm{EI}$ & 0.049 & -0.797 & -0.033 & 0.178 & 1.000 & & & \\
\hline $\mathrm{SN}$ & 0.084 & 0.068 & -0.087 & -0.035 & 0.073 & 1.000 & & \\
\hline $\mathrm{TF}$ & 0.074 & 0.061 & -0.340 & 0.042 & -0.048 & 0.064 & 1.000 & \\
\hline JP & -0.060 & 0.237 & -0.330 & 0.044 & -0.184 & 0.295 & 0.288 & 1.000 \\
\hline
\end{tabular}


MBTI and the TI. Table 5 is the resulting correlation matrix. Each of these variables was used in the canonical correlation. The significant correlations are noted in bold. The sanguine variable from the TI has a correlation of -0.797 with the EI function and a correlation of 0.237 with the JP function of the MBTI, meaning that a sanguine temperament is correlated with extroversion and perceiving. These relationships are not surprising. By definition sanguines are friendly, outgoing, and adaptable. An extrovert is defined as being sociable and enjoying people and individuals with a perceptive aptitude are often defined as spontaneous and adaptable.

The Choleric temperament is significantly correlated with the thinking and judging preferences, with a correlation of -0.340 with the TF function and a correlation of -0.330 with the JP function. Again, this not surprising when the definitions of thinking, judging, and choleric are examined. A thinking preference score shows someone who is objective and critical and a judging preference score describes someone who is good at making decisions and logical analysis. These traits would be seen in an effective and productive worker, a partial definition of someone with a choleric temperament.

The results of the canonical correlation show that there is a significant relationship between the four MBTI factors and the four TI temperaments. The null hypothesis is rejected. The output from the first step of the 
canonical correlation analysis is detailed in Table 6 . Bartlett's Test for Remaining Eigenvalues can be interpreted that two canonical variables are needed to express the dependency between the two sets of variables using a test at the 0.05 level. Two is the smallest number of eigenvalues such that the test of the remaining eigenvalues is not significant. The canonical correlation, is 0.82 , representing $67 \%$ overlapping variance between the first pair of canonical variates. The second canonical correlation is 0.43 , representing $19 \%$ overlapping variance between the second pair of canonical variates. The first two eigenvalues account for the significant linkages between the two sets of variables. The remaining two eigenvalues were not significant, accounting for less than $3 \%$ of the overlapping variance.

Table 6

Bartlett's Test for Remaining Eigenvalues

\begin{tabular}{lcrrrr}
\hline $\begin{array}{l}\text { Eigen- } \\
\text { value }\end{array}$ & $\begin{array}{c}\text { Canonical } \\
\text { Correlation }\end{array}$ & $\begin{array}{c}\text { Number of } \\
\text { Eigenvalues }\end{array}$ & $\begin{array}{c}\text { Chi } \\
\text { Square }\end{array}$ & d.f. $\begin{array}{c}\text { Signifi- } \\
\text { cance }\end{array}$ \\
\hline & & & 143.65 & 16 & 0.00 \\
0.67 & 0.82 & 1 & 25.06 & 9 & 0.00 \\
0.19 & 0.43 & 2 & 2.59 & 4 & 0.63 \\
0.02 & 0.15 & 3 & 0.01 & 1 & 0.91 \\
0.00 & 0.01 & & & & \\
\hline
\end{tabular}

Critical to interpretation are the loading matrices shown in Table 7. Correlations between variables and canonical variates greater than 0.30 were considered 
eligible for interpretation (Tabachnick \& Fidell, 1983). With a cutoff correlation of 0.30 for interpretation, the variable relevant to the first canonical variate in the $\mathrm{TI}$ set is sanguine. Among the MBTI variables, only the EI variable was relevant. The first canonical variate indicates that a high sanguine (0.99) tends to be related to the low end of the EI scale $(-0.99)$. The second canonical variate indicates that a high Choleric score (0.98) tends to be related to the lower end of the TF scale (-0.82) and the lower end of the JP scale (-0.75).

\section{Table 7}

Canonical Variable Loadings

Coefficients for Canonical Variables of the First set:

Phlegmatic

Sanguine

Choleric

Melancholy

\section{Function 1}

$-0.06$

0.99

0.01

$-0.22$
Function 2

$-0.05$

$-0.06$

0.98

$-0.21$

Coefficients for Canonical Variables of the second set:

EI

SN

$\mathrm{TF}$

JP
Function 1

$$
-0.99
$$

0.06

0.04

0.28
Function 2

$-0.06$

$-0.24$

$-0.82$

$-0.75$

\section{Interpretation}

The results of the canonical correlation did reveal an overall correlation between the MBTI's four psychological types and the TI's four temperaments. It 
did not, however, show a correlation between every type and every temperament.

The sanguine temperament appeared to be associated with extroversion both in the simple correlational analysis and the canonical correlation. Since the literature describes both extroverts and sanguines as having the same personality characteristics (outgoing, friendly, one who enjoys people), this result is not surprising. Blitchington and Cruise (1979) state that "Sanguines personify the term 'extrovert'" (p. 16). The simple correlational analysis also yielded a correlation between the sanguine temperament and the judging preference type, which was not determined to be significant in the canonical correlation.

As in the simple correlational analysis, the canonical correlation found the choleric temperament appeared to be associated with the thinking and judging preferences. Again, the results are not surprising based on the definitions found in the literature. 
CHAPTER 5

SUMMARY, CONCLUSIONS, AND RECOMMENDATIONS

\section{$\underline{\text { Summary }}$}

This section summarizes the problem, purpose of the study, the literature reviewed, the methodology followed, and the findings.

\section{Problem and Purpose}

Among the many theories that have been developed to explain differences and similarities in individual personalities are those of psychological types and temperaments. The purpose of this study was to determine whether there was a statistically significant relationship between the two constructs of psychological types, as measured by the MBTI, and temperaments, as measured by the TI.

\section{Literature Review}

The four-factor theory of personality is the prevailing theory found in the literature. Jung, Myers, Cruise, Buss, Eysenck, and others all have variations on four-factor theory. Other authors, such as cloninger, have suggested a three-factor theory, while Digman 
suggests a five-factor model.

The MBTI is an instrument designed to measure Jung's theory of psychological types. It appears to be the most common and most widely researched instrument based on Jung's theory. Several instruments have been created based on Eysenck's theory. The TI was chosen because of the ability to score individuals on each of the temperaments in Eysenck's four-temperament theory.

\section{Methodology}

A canonical correlation analysis was completed to determine whether a correlation existed between the four preference scores of the MBTI and the scores on each of the four temperaments measured by the TI. A significance level of 0.05 was used.

\section{Findings}

Results of the canonical correlation indicated that there is a significant relationship between psychological types, as measured by the MBTI, and temperaments, as measured by the TI. A preference for extroversion on the EI preference scale of the MBTI was correlated with a high Sanguine temperament score on the TI. A preference for thinking on the TF preference scale and for judging on the JP preference scale of the MBTI was correlated with a high Choleric temperament score on the TI. Other MBTI preferences are not significantly correlated with a specific temperament. 
Conclusions

The constructs of psychological types and temperaments should not be considered to be completely independent. Individuals with a choleric temperament will tend to have thinking and judging preferences. Individuals with a sanguine temperament will tend to be extroverted. And although the definitions vary (psychological types tend to be defined as processes, while temperament tends to be defined as how people react to situations, or their behavior), each has a bearing on the other. If you understand someone's psychological type, you can better estimate how they may react in a certain situation. The opposite is also true: a person's behavior gives you insights into how they are perceiving the situation.

\section{$\underline{\text { Recommendations }}$}

It may be of use to duplicate this study with individuals of a wider age range, ethnic background and professional experience. Many researchers debate the impact of genetics on behavior and temperament because of the aspects of temperament that can be seen in very young children (Plomin \& Dunn, 1986). At the same time, "Jungian theory suggests that a balance between opposing functions should be developed later in life" (McCrae \& Cost, 1989, p. 27). The sample chosen here was predominantly young adults, and the results may differ 
with an older or a younger sample.

In addition, the intra-inventory correlations found among the variables of the TI were higher than expected and higher than those found in the development of the TI. This may be because of the similarity of the individuals completing the TI and the relatively small sample size. It is also suggested that further research be completed to examine the combination of psychological types (the four-letter combination of preference scores) and the interactions of psychological temperaments. 
APPENDIX

Demographic Questionnaire

Thank you for taking the time to complete the Myers-Briggs Type Indicator and the Temperament Inventory. Directions are provided at the top of each instrument. Do not put your name and address on the instruments unless you would like the results sent to you.

The information from these forms will be confidential. This sheet will provide additional demographic information about you; if you do not wish to answer any of the questions, just leave them blank.

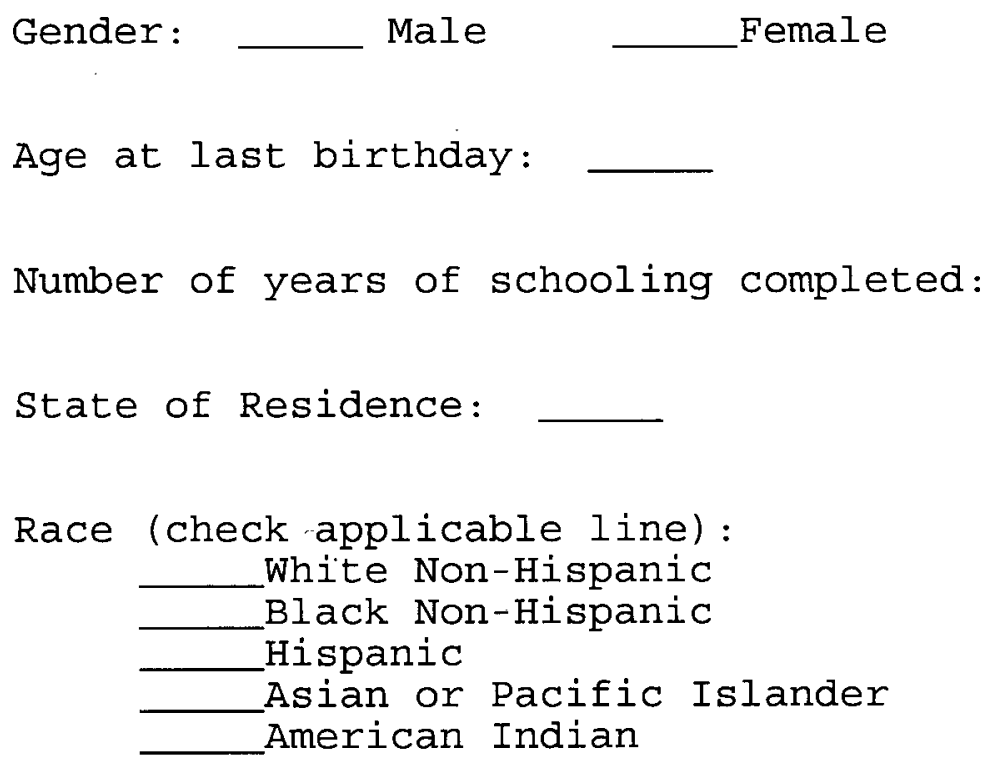




\section{Myers-Briggs Type Indicator ${ }^{\circledR}$}

\section{Form G - Self-Scorable Question Booklet}

Katharine C. Briggs

Isabel Briggs Myers

\section{Directions}

There are no "right" or "wrong" answers to these questions. Your answers will help show how you like to look at things and how you like to go about deciding things. Knowing your own preferences and learning about other people's can help you understand where your special strengths are, what kinds of work you might enjoy, and how people with different preferences can relate to each other and be valuable to society.

Read each question carefully and mark your answer on the separate answer booklet. Make no marks on this question booklet. Do not think too long about any question. If you cannot decide how to answer a question, skip it and return to it later.

When reading the questions, be sure to follow the question numbers and work ACROSS the page from left to right. When you mark your answers on the separate answer booklet, you will also work across the page.

There are two parts to this question booklet. Part I is above the shaded line; the instructions for this part are at the top of the page. Part II is below the shaded line; the instructions for this part are at the bottom of the page. Be sure to read and follow the separate directions for each part.

Read the directions on the front of the answer booklet. After reading each question, mark your answer by making an " $X$ " in the appropriate box.

When you finish answering all the questions, read the directions at the bottom of your answer booklet for how to score your MBTI ${ }^{\text {ry }}$. Be sure to turn in your question booklet when you have finished with it.

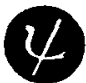

Consulting Psychologists Press, Inc. 577 College Avenue, Palo Alto, CA 94306
Copyright $\odot 1987$ by Consulting Psychologists Press. Inc. This booklet contains materials from the Myers-Briggs Type Indicator, copyright (1) 1943, 1944,1957 by Katharine C. Brigos and Isabel Briggs Mvers; copyright $01962,1976,1977$ by Isabel Briggs Myers. It is a violation of copyright law to reproduce any portion of this booklet by any process or to enter any part of its contents into a computer without the written permission of the Publisher. Myers-Briggs Type indicatort is a registered trademark and MBTT is a trademark of Consulting Psychologists Press, Inc. Printed in the U.S.A. Sixth printing, 1990. 
PART I (above the shaded line). Which Answer Comes Closer to Telling How You Usually Feel or Act? WORK ACROSS
1. Are you usually
(A) " "gind miver:," "r
(B) rather quiet and reserved?
2. If you were a teacher, would yous
tollher terth
3. Do you more often let
(A) fut courses, or
(B) courses involving theory?
(A) your heart rule your hodud, or
4. When you gor somewhere for the
(A) plon whou rather
(B) courses involving theory? $\quad$ when, or
\begin{tabular}{llll}
\hline 5. When you are with a group of peo- & 6. Do you usually get along better with & 7 . Is it a higher compliment lo be & 8. Do you prefer to \\
ple, would you usually rather & (A) imaginative people, or & (A) arrange dates,
\end{tabular}

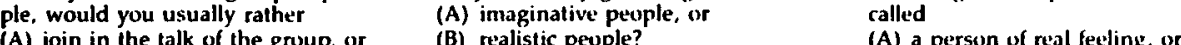
Do you prefer to
(A) join in the talk of the group, or
person?
(A) arrange dates, parties, etc., well
(B) be free to do whatever looks like fun when the time comes?
9. In a large group, do you more ofien 10. Would you rather be considered
$\begin{array}{ll}\text { (A) introduce others, or } & \text { (A) a practical person, or } \\ \text { (B) get introduced? } & \text { (B) an ingenious person? }\end{array}$
(A) value sentiment more than logic.
or
(B) value logic more than senti- ment?
11. Do you usually
2. Are you more successful
(A) at dealing with the unexpected at dealing with the unexpected
and seeing quickly what should
(B) at following a carefully worked at following
out plan?
13. Do you tend to have
(A) deep friendships with a very
(B) few people, or broad friendships with many
different people?
17. Among your friends, are you (A) one of the last to hear what is
Among your friends, are you
going on, or
(B) full of news aboul everybody?
14. Do Do you admire mure the people who
are conventional enuugh never to
(A) conses themselves conspiruous,
make
or
(B) too original and individual to
care whether they are conspic-
uous or not?
18. Would you rather have as a friend
(A) someone who is always cuming
up with new ideas, or (B) someone who has both feet on
the ground?
19. Would you
one who is
(B) always fair?
(A) unsympathetic, or
(A) appeal to you, or
(B)
(B) cramp you?
21. Do you
(A) talk easily to almost anyone for
as long as you have to, or
(B) find a lot to say only fo certain
people or under certain condi-
22. In reading for pleasure, do you
(A) enjoy odd or original ways of
saying things, or
23. Do you feel it is a worse fault
(B) like writers to say exactly what
(A) to show too much warmth they mean?
(B) not to have warmth enough?
24 In your daily work, do you
(A) rather enjoy an emergency that
makes you work against time, or
(B) hate to work under pressure, or
C) usually plan your work so you won't need
pressure?
25. Can the new people you meet lell
what you are interested in
(A) right away, or
(B) only after they really get to
26. In doing sumething that many ou
people do, does it appeal to you
more to
(A) do it in the accepled way, of
Are you nuore carciul aboul (B) invent a way of your own?
(A) peoples reelings, or
28. When you have a special job to do, do you like to
(A) organize it carefully before you start, or
PART II (see instructions below).
29. Du you usually
(A) show your feclings ifeely, or
30. In your way of living, do you prefer to b find out what is
you go along?
(A) genile
(B) firm
32. When it is settled well in advance
hat you will do a certain thing al 


\begin{tabular}{|c|c|c|c|c|c|c|c|}
\hline & & & (B) conventional? & & & & $\begin{array}{l}\text { (A) nice to be able to plan accord- } \\
\text { ingly, or } \\
\text { (B) a litte unpleasant to be tied } \\
\text { down? }\end{array}$ \\
\hline & $\begin{array}{l}\text { Would you say you } \\
\text { (A) get more enthusiastic about } \\
\text { things than the average person. } \\
\text { or } \\
\text { (B) get less excited about things } \\
\text { than the average person? }\end{array}$ & 34. 1 & $\begin{array}{l}\text { Is it higher praise to say sumeone } \\
\text { has . } \\
\text { (A) vision, or } \\
\text { (B) common sense? }\end{array}$ & $\begin{array}{l}\text { 35. (A) } \\
\text { (B) }\end{array}$ & $\begin{array}{l}\text { Ihinking } \\
\text { feeling }\end{array}$ & 36. & $\begin{array}{l}\text { Do you } \\
\text { (A) rather prefer to do things at the } \\
\text { last minute, or } \\
\text { (B) find doring things at the last } \\
\text { minute hard on the nerves? }\end{array}$ \\
\hline 37. & $\begin{array}{l}\text { At parties, do you } \\
\text { (A) sumetimes get bored, or } \\
\text { (B) always have fun? }\end{array}$ & 38. & $\begin{array}{l}\text { Do you think it more important to } \\
\text { be wble } \\
\text { (A) low see the possibilities in a situa- } \\
\text { tion, or } \\
\text { (B) to dodjust to the facts as they } \\
\text { are? }\end{array}$ & $\begin{array}{l}\text { 39. (A) } \\
\text { (B) }\end{array}$ & $\begin{array}{l}\text { convincing } \\
\text { tluching }\end{array}$ & 40. & $\begin{array}{l}\text { Do you think that having a daily } \\
\text { routine is } \\
\text { (A) a comfortable way to get things } \\
\text { done, or } \\
\text { (B) painful even when necessary? }\end{array}$ \\
\hline 41. & $\begin{array}{l}\text { When something new starts to be } \\
\text { the fashion, are you usually } \\
\text { (A) one of the first to try it, or } \\
\text { (B) not much inlerested? }\end{array}$ & 42. & $\begin{array}{l}\text { Would you rather } \\
\text { (A) support the established methods } \\
\text { of doing good, or } \\
\text { (B) andlyze what is still wrong and } \\
\text { stllakk unswived protlems? }\end{array}$ & $\begin{array}{l}\text { 13. (A) } \\
\text { (B) }\end{array}$ & $\begin{array}{l}\text { analyze } \\
\text { sympathize }\end{array}$ & 44. & $\begin{array}{l}\text { When you think of some little thing } \\
\text { you should do or buy, do you } \\
\text { (A) often forget it till much later, or } \\
\text { (B) ustally get it down on paper to } \\
\text { remind yourself, or } \\
\text { (C) always carry llirungh on it with- } \\
\text { out reminders? }\end{array}$ \\
\hline 45. & $\begin{array}{l}\text { Are you } \\
\text { (A) easy to get to know, or } \\
\text { (B) hard to get to know? }\end{array}$ & 46. 1 & $\begin{array}{l}\text { (A) facts } \\
\text { (B) ideas }\end{array}$ & $\begin{array}{l}\text { 47. (A) } \\
\text { (B) }\end{array}$ & $\begin{array}{l}\text { justice } \\
\text { mercy }\end{array}$ & 48. & $\begin{array}{l}\text { Is it harder for you to adapt to } \\
\text { (A) routine, or } \\
\text { (B) constant change? }\end{array}$ \\
\hline 49. & $\begin{array}{l}\text { When you are in an embarrassing } \\
\text { spot, do you usually } \\
\text { (A) change the subject, or } \\
\text { (B) lurn it into a juke, or } \\
\text { (C) days later, think of what you } \\
\text { should have said? }\end{array}$ & 50. 1 & $\begin{array}{l}\text { (A) statement } \\
\text { (B) concept }\end{array}$ & 51. (A) & $\begin{array}{l}\text { compassion } \\
\text { foresight }\end{array}$ & 52. & $\begin{array}{l}\text { When you start a big project that is } \\
\text { due in a week, do you } \\
\text { (A) take time to list the separate } \\
\text { things to be done and the order } \\
\text { of doing them, or } \\
\text { (B) plunge in? }\end{array}$ \\
\hline & $\begin{array}{l}\text { Do you think the people close to } \\
\text { you know how you feel } \\
\text { (A) about most things, or } \\
\text { (B) only when you have had some } \\
\text { special reason to tell then? }\end{array}$ & 54. 1 & $\begin{array}{l}\text { (A) theory } \\
\text { (B) certainty }\end{array}$ & 55. (A) & $\begin{array}{l}\text { benefits } \\
\text { hlessings }\end{array}$ & & $\begin{array}{l}\text { In getting a job done, do you } \\
\text { depend on } \\
\text { (A) starting early, so as to finish } \\
\text { with time to spare, or } \\
\text { (B) the extra speed you develop at } \\
\text { the last minute? }\end{array}$ \\
\hline 57. & $\begin{array}{l}\text { When you are at a party, do you like. } \\
\text { to help get things going, or } \\
\text { (A) hel the others have fun in their } \\
\text { (B) let the way? }\end{array}$ & 58. & $\begin{array}{l}\text { (A) literal } \\
\text { (B) figurative }\end{array}$ & $\begin{array}{l}\text { 59. (A) } \\
\text { (B) }\end{array}$ & $\begin{array}{l}\text { determined } \\
\text { devoled }\end{array}$ & 60. & $\begin{array}{l}\text { If you were asked on a Saturday } \\
\text { morning what you were going to do } \\
\text { that day, would you } \\
\text { (A) be able to tell pretty well, or } \\
\text { (B) list twice too many things, or } \\
\text { (C) have to wail and see? }\end{array}$ \\
\hline & $\begin{array}{l}\text { (A) hearty } \\
\text { (B) quiet }\end{array}$ & 62.1 & $\begin{array}{l}\text { (A) imaginative } \\
\text { (B) matter-of-fact }\end{array}$ & 63. (A) & $\begin{array}{l}\text { firm-minded } \\
\text { warm-hearted }\end{array}$ & 64. & $\begin{array}{l}\text { Do you find the more routine parts } \\
\text { of your day } \\
\text { (A) restful, or } \\
\text { (B) boring? }\end{array}$ \\
\hline
\end{tabular}

PART II (below the shaded line). Which Word in Each Pair Appeals to You More? (continued) Think what the words mean, not how they look or how they sound. 
PART II (continued). Which Word in Each Pair Appeals to You More?

Think what the words mean, not how they look or how they sound.

\section{WORK ACROSS}

\begin{tabular}{|c|c|c|c|c|c|c|c|c|}
\hline $\begin{array}{l}\text { 65. (A) } \\
\text { (B) }\end{array}$ & $\begin{array}{l}\text { reserved } \\
\text { talkative }\end{array}$ & 66. & $\begin{array}{l}\text { (A) } \\
\text { (B) }\end{array}$ & $\begin{array}{l}\text { make } \\
\text { create }\end{array}$ & $\begin{array}{r}\text { 67. (A) } \\
\text { (B) }\end{array}$ & $\begin{array}{l}\text { peacemaker } \\
\text { juctge }\end{array}$ & $\begin{array}{r}\text { 68. (A) } \\
(\mathrm{B})\end{array}$ & $\begin{array}{l}\text { scheduled } \\
\text { unplanned }\end{array}$ \\
\hline $\begin{array}{l}\text { 69. (A) } \\
\text { (B) }\end{array}$ & $\begin{array}{l}\text { calm } \\
\text { lively }\end{array}$ & 70. & $\begin{array}{l}\text { (A) } \\
\text { (B) }\end{array}$ & $\begin{array}{l}\text { sensible } \\
\text { fascinating }\end{array}$ & $\begin{array}{r}71 .(A) \\
(B)\end{array}$ & $\begin{array}{l}\text { soft } \\
\text { hard }\end{array}$ & $\begin{array}{l}\text { 72. (A) } \\
\text { (B) }\end{array}$ & $\begin{array}{l}\text { systematic } \\
\text { spontaneous }\end{array}$ \\
\hline $\begin{array}{l}\text { 73. (A) } \\
\text { (B) }\end{array}$ & $\begin{array}{l}\text { speak } \\
\text { write }\end{array}$ & 74. & $\begin{array}{l}\text { (A) } \\
\text { (B) }\end{array}$ & $\begin{array}{l}\text { production } \\
\text { design }\end{array}$ & $\begin{array}{r}\text { 75. (A) } \\
\text { (B) }\end{array}$ & $\begin{array}{l}\text { forgive } \\
\text { tolerate }\end{array}$ & $\begin{array}{l}\text { 76. (A) } \\
\text { (B) }\end{array}$ & $\begin{array}{l}\text { systematic } \\
\text { casual }\end{array}$ \\
\hline $\begin{array}{l}\text { 77. (A) } \\
\text { (B) }\end{array}$ & $\begin{array}{l}\text { sociable } \\
\text { detached }\end{array}$ & 78. & $\begin{array}{l}\text { (A) } \\
\text { (B) }\end{array}$ & $\begin{array}{l}\text { concrete } \\
\text { abstract }\end{array}$ & $\begin{array}{l}\text { 79. (A) } \\
\text { (B) }\end{array}$ & $\begin{array}{l}\text { who } \\
\text { what }\end{array}$ & $\begin{array}{r}\text { 80. (A) } \\
\text { (B) }\end{array}$ & $\begin{array}{l}\text { impulse } \\
\text { decision }\end{array}$ \\
\hline \multirow[t]{6}{*}{$\begin{array}{l}\text { 81. (A) } \\
\text { (B) }\end{array}$} & $\begin{array}{l}\text { party } \\
\text { theater }\end{array}$ & 82. & $\begin{array}{l}\text { (A) } \\
\text { (B) }\end{array}$ & $\begin{array}{l}\text { build } \\
\text { invent }\end{array}$ & $\begin{array}{r}\text { 83. (A) } \\
\text { (B) }\end{array}$ & $\begin{array}{l}\text { uncritical } \\
\text { critical }\end{array}$ & $\begin{array}{l}\text { 84. (A) } \\
\text { (B) }\end{array}$ & $\begin{array}{l}\text { punctual } \\
\text { leisurely }\end{array}$ \\
\hline & & 85 & $\begin{array}{l}\text { (A) } \\
\text { (B) }\end{array}$ & $\begin{array}{l}\text { foundation } \\
\text { spire }\end{array}$ & $\begin{array}{r}86 . \\
(\mathrm{A}) \\
(\mathrm{B})\end{array}$ & $\begin{array}{l}\text { wary } \\
\text { trustful }\end{array}$ & $\begin{array}{r}\text { 87. (A) } \\
\text { (B) }\end{array}$ & $\begin{array}{l}\text { changing } \\
\text { permanent }\end{array}$ \\
\hline & & 88. & $\begin{array}{l}\text { (A) } \\
\text { (B) }\end{array}$ & $\begin{array}{l}\text { Theory } \\
\text { experience }\end{array}$ & $\begin{array}{r}\text { 89. (A) } \\
\text { (B) }\end{array}$ & $\begin{array}{l}\text { agree } \\
\text { discuss }\end{array}$ & $\begin{array}{r}\text { 90. (A) } \\
\text { (B) }\end{array}$ & $\begin{array}{l}\text { orderly } \\
\text { easygoing }\end{array}$ \\
\hline & & 91. & $\begin{array}{l}\text { (A) } \\
\text { (B) }\end{array}$ & $\begin{array}{l}\text { sign } \\
\text { symbol }\end{array}$ & & . & $\begin{array}{r}\text { 92. (A) } \\
\text { (B) }\end{array}$ & $\begin{array}{l}\text { quick } \\
\text { careful }\end{array}$ \\
\hline & & 93. & $\begin{array}{l}\text { (A) } \\
\text { (B) }\end{array}$ & $\begin{array}{l}\text { accept } \\
\text { change }\end{array}$ & & & & \\
\hline & & 94. & $\begin{array}{l}\text { (A) } \\
\text { (B) }\end{array}$ & $\begin{array}{l}\text { known } \\
\text { unknown }\end{array}$ & & & & \\
\hline
\end{tabular}




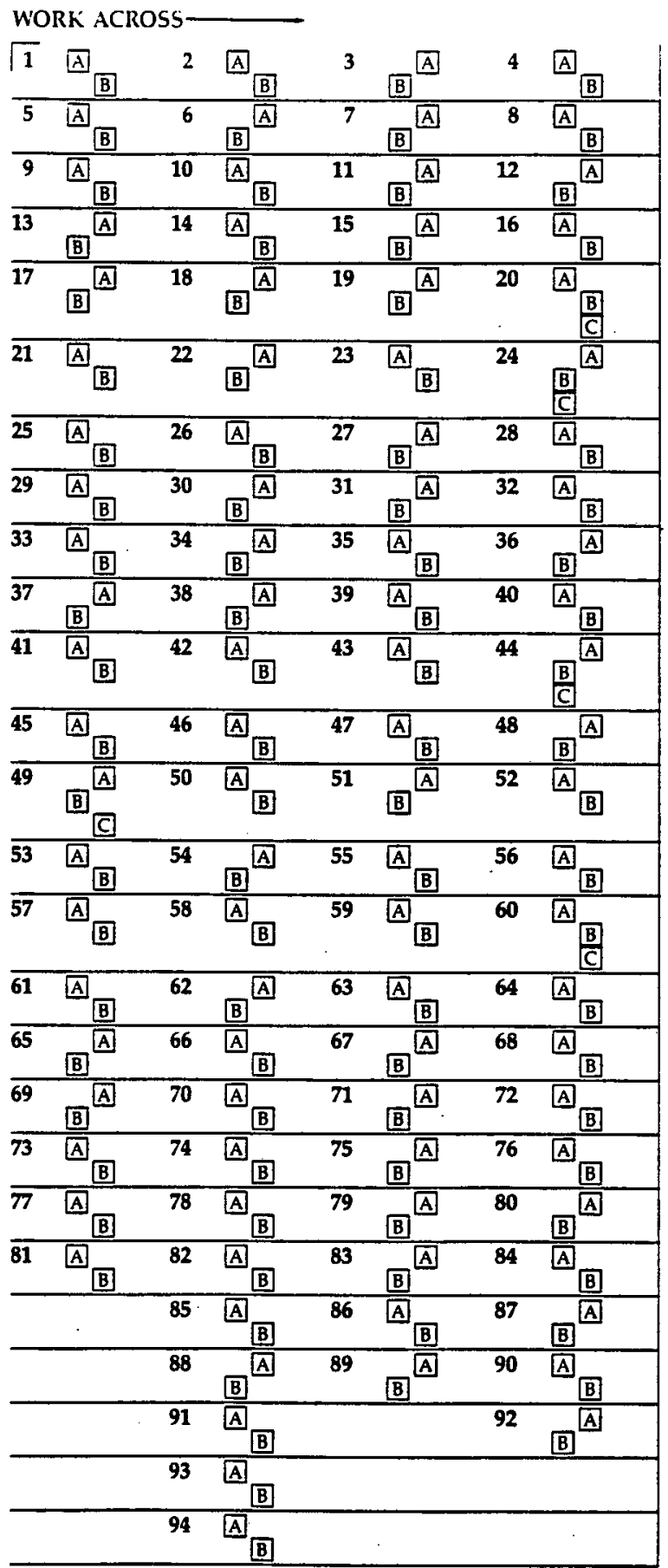

\section{Myers-Briggs Type Indicator ${ }^{\mathrm{TM}}$} Form G - Self-Scorable Answer Booklet

\section{Directions}

Mark your answers by making an " $X$ " in the appropriate box. If you make a mistake, simply blacken in the box where the error is-do not erase. The numbers go ACROSS the page, just like the questions in the question booklet.

When you have answered every question, open this booklet and follow the directions for scoring.

Name:

Date: Sex: $M \square F \square$ Age:

Occupation:

Years of schooling:

Group:

\section{Consulting Psychologists Press}

577 College Avenue, Palo Alto, California 94306

Copyright 01987 by Consulting Psychologists Press, Inc. This booklet contains materials from the Myers-Briggs Type Indicator, copvright (1943. 1944, 1957 bv Katharine C. Briggs and Isabel Briggs Mvers: copyright $01962,1976,1977$ by Isabel Briggs Mvers. It is a violation copyright $1962,1976,1977$ by lsabel Briggs Mvers. It is a violation of copyright law to reproduce any portion of this booklet by any process or to enter any part he publisher. Mvers-Briggs Type Indicator ${ }^{\text {* }}$ and $\mathrm{MBT}$ " ${ }^{m}$ are trademarks of Consulting Psychologists Press, Inc. Printed in the USA. Second printing, 1988. 


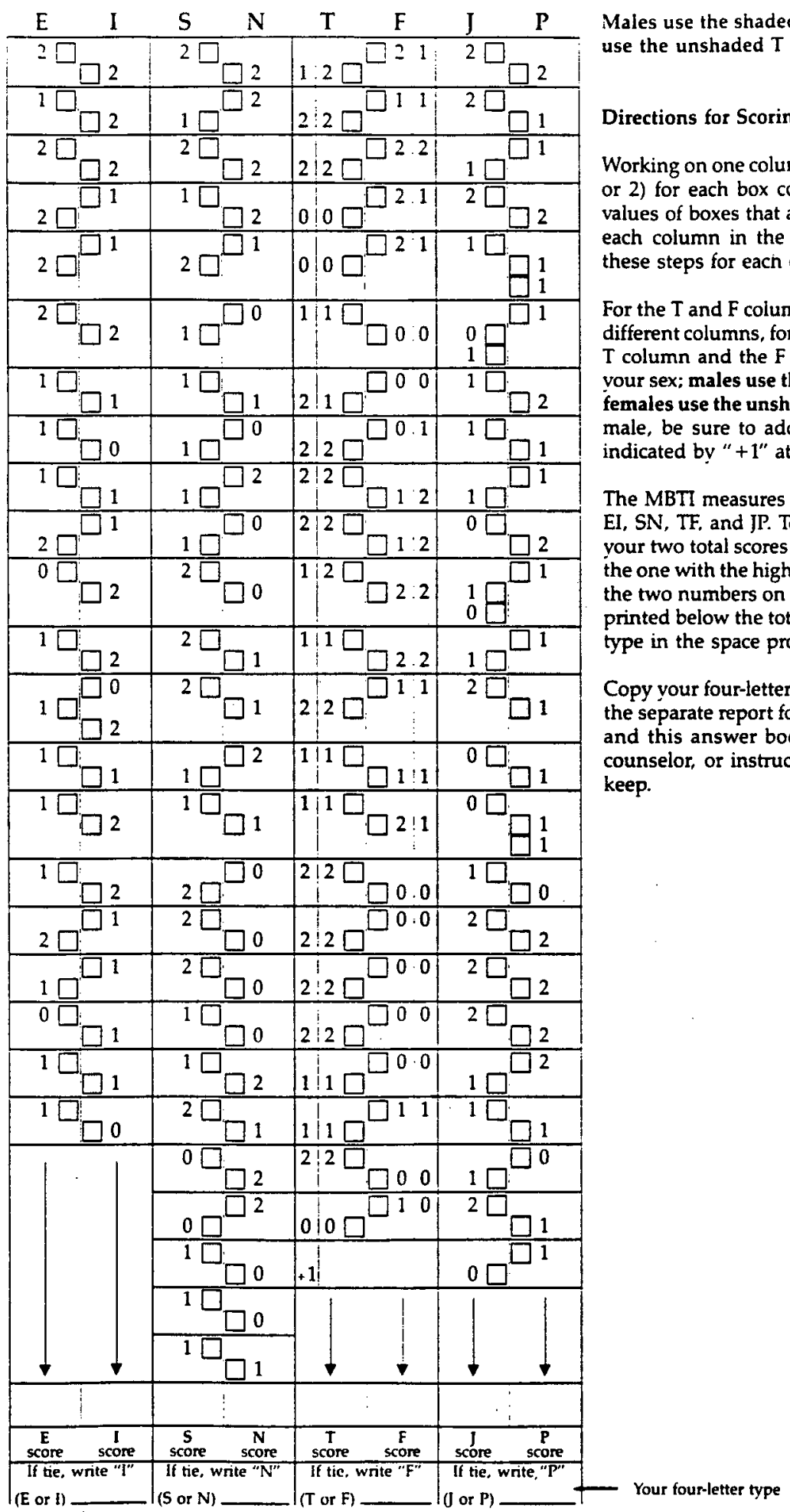




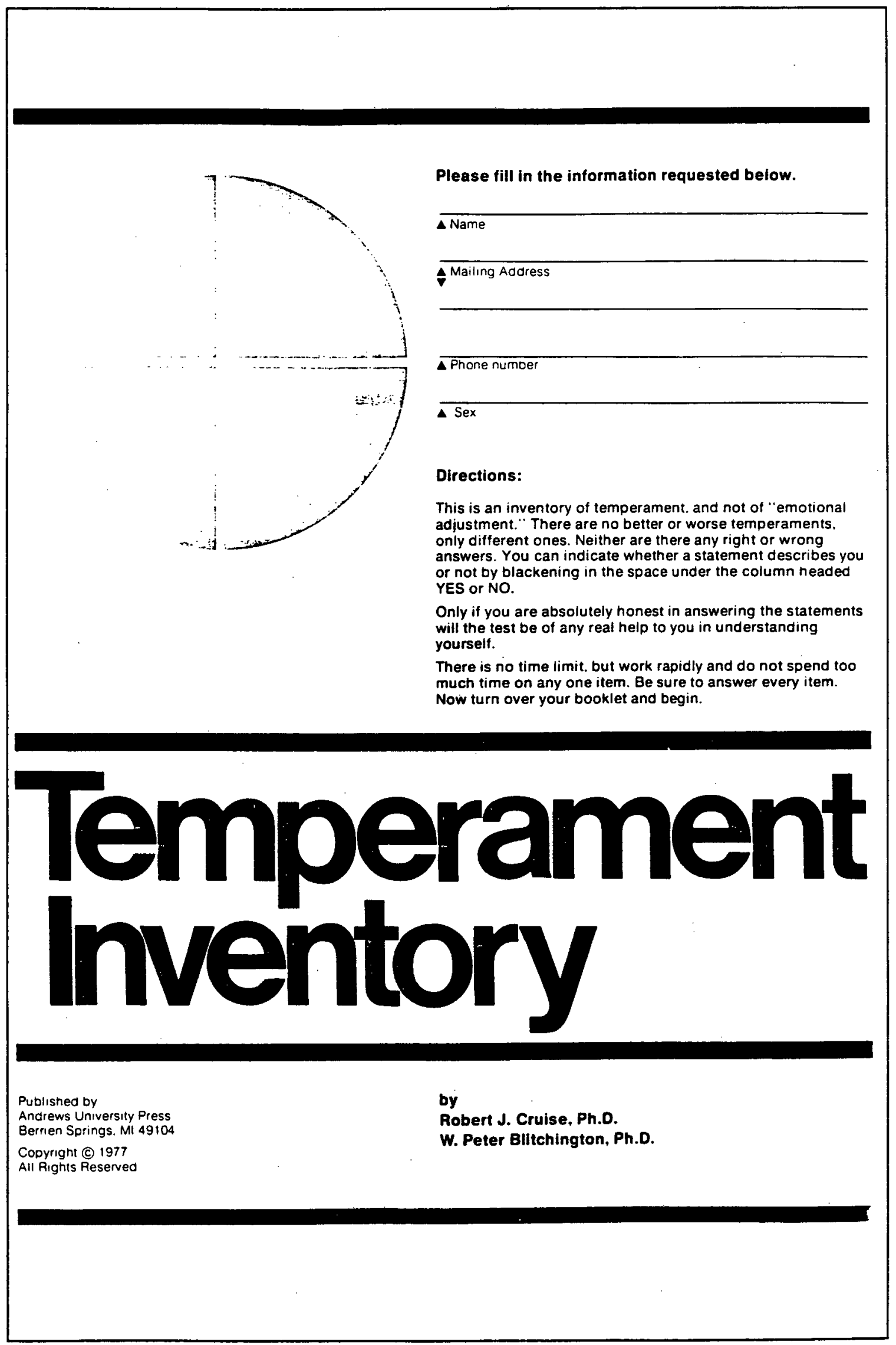


Put your answers to this page in Column 1.

1. I succeed when some people tail, not because my pians are better, but because I keep pusning when they get discouraged and quilt.

2. My calm. tranquil nature usually keeps me from geitng upset in the face of externat turmoil or stress.

3. I seem to be able to diagnose fairly accurately the oostacies and dangers of projects I am planning.

4. I'm annoyed by the enthusiasm of some people. ano I guess I kind of needle them sometumes

5. I usually allow other people to meet me. rather than oushing forward to meet them.

6. My leacership ability is more the result of drive ano persistence than charisma.

7. I am not able to converse easily with other people. but I'm pretty good at sizing them up and analyzing them.

8. I frequently find myself arriving tate for engagements and torgetting resolutions.

9. I am more the kind of person who is deeply loyal to the tew triends I have than the kind of person who has a fot of friends

10. I tend to be motivated by the crowd (or situation). If they are busy I get busy. if they aren I I'm not. .

11. I am seff-motivated. If something is there to be done. I can't be satisfied until I've completed it.

12. I usually preter solitary activities, such as reading, 10 activities which involve other people.

13. I go over and over decisions after I make them, asking myselt if I chose right.

14. I sometimes only halfheartediy help others because ceep down inside I think I have a better plan and an easier way.

15. I tend to remember when people have insulted me and to think about it every now and then.

16. I really enjoy myself. and my attitude seems to be contagious to those around me.

17. In my introspection I tend to relive over and over again the events of the past.

18. I have a tairly keen mind and can usually ptan wortnwnile long-range projects

19. I'd probably be more sociable if I weren $t$ afraid peodie would reject me.

20. I like to be where there is something going on all the time

21. It makes me gloomy when other people ignore or avoid me.

22. Some people say that I am a born leader because of my tendency to "take over."

23. I know where I want to go and I usually discipline myselt to get there.

24. I have a tendency to hold grudges against people who are rude to me.

25. I teno to be emotional. Things arouse or upset me pretty easily.

26. It usually takes something drastic to get me excited or upset.

27. I have a rather even-tempered emotional response to inings. 
Put your answers to this page in Column 2.

28. Sometimes when I see Iwo people laughing. I wonder if they' re laughing at me.

29. I have a pretty even disposition. not too many ups and downs

30. My friends would describe me as relaxed and even-tempered.

31. I should have more self-confidence: I tend to under-estimate my abilities.

32. If a job needs to be done I do it regardless of how unpleasant it is

33. I tend to reflect a good deal on my dreams, hopes, and aspirations

34. I can put up with frustration without becoming depressed or angry.

35. I make new triends so easily that I tend to forget old friends.

36. I would 't mind betonging to several clubs at the same time.

37. I have a tendency to think gloomy. pessimistic thoughts.

38. I often have trouble finishing things that I've started

39. In social situations, I am talkative and spontaneous

40. I am usually uncomtortable in a group of people

41. I enjoy people and just like to be around them.

42. I should probably be less moody and sensitive.

43. I have a somewhat defensive. touchy nature

44. Sometimes I think about getting revenge tor old wrongs

45. Adversity just stimulates me to push a little harder.

46. Im somewhat serious and very deeply emotionat.

47. I like to spend time planning things way ahead of time

48. I have a warm spirit. I am lively and enjoy living.

49. By nature I seem to be a pretty good "peacemaker.".

50. My friends consider me to be a tacttul person

51. I tend to be pretty toterant of other people.

52. I am usually very well organized in my work

53. When things go wrong ! knuckle down and try harder

54. I have a pretty good ability to get things done 
Put your answers to this page in Column 3.

55. I am calm and relaxed, and rather unemotional.

56. I tend to get my feelings hurt fairiy easily.

57. I see myself as a cheerful, sociable person.

58. I have a tendency to feel sorry for myself.

59. Socially, I am a pretty outgoing person.

60. A strong wiil is one of my best assets

61. I usually have a good time at parties.

62. I usually make new friends easily.

63. My life is tast-paced and active.

64. I need to learn to worry less.

65. I teno to move and speak slowly and caimiy.

66. I have a tendency to brood about things.

67. I teno to be a pretty easygoing person.

68. I usually finish whatever I begin.

69. Idon't get upset very often.

70. I'm rarely at a loss for sometning to say.

71. I usually get a lot of fun out of life

72. My friends would call me an extrovert.

73. I tend to analyze myself frequently.

74. Untinished tasks really bother me.

75. I don't get ruffled easily.

76. I tend to be a hard. persistent worker.

77. I tend to resent people who oppose me.

78. I seldom get angry or overemotional.

79. I don't make friends very easily.

80. I should probably be less lazy. 
Temperament Imventory, Score Summary Sheet Score Summary

Column 3 Column 2 Column 1
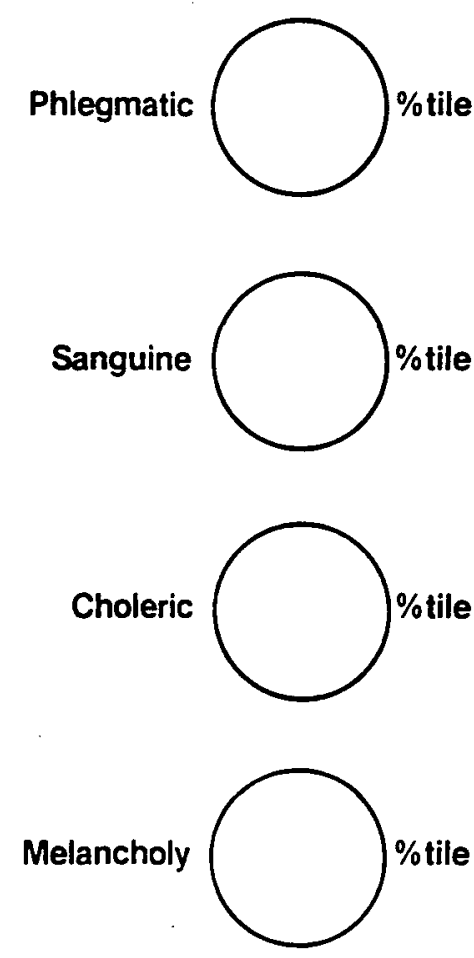


\section{BIBLIOGRAPHY}

Blitchington, P., \& Cruise, R. J. (1979). Understanding your temperament. Berrien Springs, MI: Andrews University Press.

Buss, A. H., \& Plomin, R. (1975). A temperament theory of personality development. New York: John Wiley \& Sons.

Cruise, R. J., Blitchington, W. P., \& Futcher, W. G. A. (1980). Temperament Inventory: An instrument to empirically verify the four-factor hypothesis. Educational and Psychological Measurement, 40, 943954.

Diamond, S. (1957). Personality and temperament. New York: Harper \& Brothers.

Giovannoni, L. C., Berens, L. V., \& Cooper, S. A. (1988). Introduction to temperament. Huntington Beach, CA: Telos Publications.

Johnson, D. A. \& \& Saunders, D. R. (1990). Confirmatory factor analysis of the Myers-Briggs Type Indicator: Expanded analysis report. Educational and Psychological Measurement, 50, 561-71.

Keirsey, D., \& Bates, M. (1984). Please understand me. Delmar, CA: Prometheus Nemesis Book Company.

Kraemer, H. C., \& Thiemann, S. (1987). How many subjects? New York: Sage Publications.

McClowry, S. G. (1992). Temperament theory and research. IMAGE Journal of Nursing Scholarship, 24, 319-325.

McCrae, R. R., \& Costa, P. T. (1989). Reinterpreting the Myers-Briggs Type Indicator from the perspective of the five-factor model of personality. Journal of Personality, 57, 17-40. 
Myers, I. B. (1987). Introduction to type. Palo Alto, CA: Consulting Psychologists Press.

Myers, I. B., \& McCaulley, M. H. (1985). Manual: A guide to the development and use of the Myers-Briggs Type Indicator. Palo Alto, CA: Consulting Psychologists Press.

Plomin, R., \& Dunn, J. (1986). The study of temperament: Changes, continuities and challenges. Hillsdale, NJ: Lawrence Erlbaum Associates.

Stelmack, R. M., \& Stalikas, A. (1991). Galen and the humour theory of temperament. Personality and Individual Differences, 12, 255-263.

Tabachnick, B. G., \& Fidell, I. S. (1983). Using multivariate statistics. New York: Harper \& Row Publishers.

Tatsuoka, M. M. (1988). Multivariate analysis. New York: Macmillan Publishing Company.

White, K. M., \& Speisman, J. C. (1982). Research approaches to personality. Monterey, CA: Brooks/Cole Publishing Company.

Windle, M. (1989). Temperament and personality: An exploratory interinventory study of the DOTS-R, EASIII and EPI. Journal of Personality Assessment, 53, $487-501$. 


\section{RONDA F. DAUGHERTY \\ 25063 Dartmouth, Dearborn Heights, MI 48125}

(313) $562-8847$

\section{Professional Experience:}

Senior Consultant, The MEDSTAT Group, Ann Arbor, MI April 1993 to Present

Oversee the design and installation of customized database software for insurance and managed-care organizations. Provide data management training to clients and in-house data managers addressing database design, data quality and program specification development.

Research Assistant, Wayne State University, Detroit, MI March 1991 to May 1993

Assisted all attending and resident staff in the designing and statistical analysis of clinical studies within the department of surgery. Maintained a database of all operative experience of resident staff. Provided computer support, training and maintenance for the department.

Research Analyst, Illinois Criminal Justice Information Authority, Chicago, IL May 1990 - March 1991

Responsible for all areas of the Pretrial Release study including database design, data quality, and statistical analysis. Developed and presented grant proposals.

Instructor, Graduate School of Education Andrews University, Berrien Springs, MI Fall Quarter 1989

Taught EDRM 519, Statistics II, a graduate level statistics course focusing on analysis of variance and multiple regression.

Instructor

Southwestern Michigan College, Dowagiac, MI Fall Semester 1989

Taught Math 150, Introduction to Statistics.

\section{Educational Background:}

B.S. Social Services - 1988

Southwestern Adventist College, Keene, TX 